J. Clin. Chem. Clin. Biochem.

Vol. 19, 1981, pp. 953-960

\title{
Kinetic and Inhibition Studies of Bacillus cereus $\beta$-Lactamase Using a Spectrophotometric Method
}

\author{
By R. Münch, H. Wombacher and F. Körber \\ Zentralinstitut für Biochemie und Biophysik der Freien Universität Berlin, Bundesrepublik Deutschland \\ und Departement für Innere Medizin der Universität Zürich, Schweiz
}

(Received May 27, 1980/March 18, 1981)

Summary: The use of a spectrophotometric method is reported for the characterization of a $\beta$-lactamase (EC 3.5.2.6) from Bacillus cereus. Absorption coefficients of the mercaptids of various penicillins were determined with this method. The enzyme was kinetically characterized using penicillins.

Inhibition studies with Bacillus cereus $\beta$-lactamase and various penicillins showed a substrate type of inhibition, indicating an additional binding site for substrates without catalytic activity.

The dissociation constant of this binding site was determined and the influence of this binding site upon the catalytic activity is discussed. Studies with $\beta$-lactamase-stable penicillins as inhibitors and various penicillins showed different types of inhibition, which indicated the presence of an additional cataly tically inactive binding site. Experiments with clavulanic acid, a $\beta$-lactamase inhibitor without remarkable intrinsic antibacterial activity, showed a mixed type of inhibition. Based on the hypothesis for the existence of more than one substrate binding site on the enzyme, clavulanic acid was found to be bonded to both the catalytic active and the catalytic inactive binding site.

\section{Kinetische Untersuchungen und Hemmungsstudien an einer $\beta$-Lactamase aus Bacillus cereus mit einer spektrophoto- metrischen Methode}

Zusammenfassung: Wir haben eine photometrische Methode zur Bestimmung von Penicillinen für die Charakterisierung einer $\beta$-Lactamase (EC 3.5.2.6) aus Bacillus cereus angewendet und die molaren Absorptionskoeffizienten der aus verschiedenen Penicillinen gebildeten Mercaptide bestimmt. Das kinetische Verhalten des Enzyms wurde unter Verwendung verschiedener Penicilline überprüft.

Untersuchungen mit hohen Substratkonzentrationen ergaben für die $\beta$-Lactamase aus Bacillus cereus mit verschiedenen spaltbaren Penicillinen das Bild einer Substratüberschußhemmung. Aufgrund dieses Hemmtyps wird neben der katalytisch aktiven Stelle eine weitere, substratbindende Stelle auf der untersuchten $\beta$-Lactamase vermutet. Die Dissoziationskonstänte dieser Bindungsstelle wird bestimmt und der Einfluß dieser nicht katalytisch aktiven Stelle auf die katalytisch aktive Stelle diskutiert. Versuche mit $\beta$-Lactamase-festen Penicillinen als Inhibitor und verschiedenen Penicillinen ergaben unterschiedliche Hemmtypen, die unter Einbeziehung der postulierten katalytisch inaktiven, substratbindenden Stelle erklärt werden. Clavulansäure, ein $\beta$-Lactamase-In'libitor ohne nennenswerte eigene antimikrobielle Aktivität, zeigte das Bild eines gemischten Hemmtyps. Unter Zugrundelegung der Mehrbindungsstellenhypothese besetzt Clavulansäure sowohl die katalytisch aktive, als auch die katalytisch inaktive Bindungsstelle.

\section{Introduction}

Since the discovery of penicillinase in 1940 by Abraham $\&$ Chain (1) and the recognition of the importance of B-lactamases in the resistance of Staphylococci to naturally occurring penicillins $(2,3)$, there has been intensive research for inhibitors of this enzyme.

It was shown that some semisynthetic penicillins, such as methicillin and the isoxazolylpenicillins, act synergistically with broad spectrum penicillins $(4,5)$ by inhibiting the $\beta$-lactamase, thus protecting the suscept- ible penicillin from enzymatic inactivation. The inhibition of a Bacillus cereus $\beta$-lactamase by oxacillin, methicillin and nafcillin has been described as competitive $(6,7)$, but other observations indicate that a more complex molecular interaction exists between the enzyme and the inhibitor $(8,9,10)$.

A new approach, using the principle of $\beta$-lactamase inhibition in the therapy of infectious diseases, was made possible by the discovery of substances produced by several Streptomyces species (11). These substances have only a weak broad spectrum antibacterial activity 
but they do have a potent inhibitory effect against several $\beta$-lactamases. Clavulanic acid, a metabolite produced in a culture of Streptomyces clavuligerus, was discovered in 1976 (12) and first studied in detail in 1977 (13). It acts as a potent inhibitor of several $\beta$-lactamases from Richmond types II, III, IV and V (14). The inhibition is described by Reading \& Cole (13) as "progressive"; this assumes a molecular mechanism different from that of competitive inhibition.

The aim of our study was to estimate $V$ and $K_{\mathrm{m}}$ of a Bacillus cereus $\beta$-lactamase using a spectrophotometric method (15) with enzymatically hydrolysable penicillins as substrates, and to examine the influence of several inhibitors on the interaction of enzyme and substrates.

\section{Material and Methods}

\section{Enzyme}

Penicillinase (penicillin amido- $\beta$-lactamhydrolase EC 3.5.2.6) was a commercially available preparation of Riker Laboratories Northridge, California (penicillinase Riker), extracted from cultures of Bacillus cereus. One vial contained 800000 Levy units (16a) or 1340 intemational units.

The enzyme was a pharmaceutical preparation of an exoenzyme from Bacillus cereus $\mathrm{H}$ 569. It was prepared for clinical use according to a patented method (US patent No. $2,982,646$ ) by ion exchange (IRC 50 resin) and ly ophilization. The extracellular $\beta$-lactamase activity in cultures of Bacillus cereus can be shown to consist chiefly of a type I $\beta$-lactamase with penicillinase activity, accompanied by a very small proportion of a type II $\beta$-lactamase with cephalosporinase activity. The cephalosporinase activity is easily separated from type I $\beta$-lactamase by the usual purification procedures, such as that used by the manufacturer; it is absorbed by, but not eluted from cellulose phosphate $(16 \mathrm{~b}, 16 \mathrm{c})$. In addition this cephalosporinase requires zinc for activity, and no zinc was added to our assays. We therefore consider it impossible that any interference by cephalosporinase contamination in our measurements of type I $\beta$-lactamase activity was greater then the inherent experimental error of the assay method.

\section{Substrates, inhibitors, reagents}

The lactam content of the $\beta$-lactamase susceptible penicillins was estimated by enzymatic hydrolysis, that of cloxacillin by alkaline hydrolysis according to Körber et al. (17). Benzylpenicillin sodium (lactam fraction 0.970 ), phenoxymethylpenicillin potassium (lactam fraction 0.976 ) and ampicillin sodium (lactam fraction 0.920 ) were given by Hoechst AG (Frankfurt, FRG), phenoxyethylpenicillin (lactam fraction 0.817 ) and phenoxypropylpenicillin (lactam fraction 0.930 ) were supplied by Bayer AG (Leverkusen, FRG), carbenicillin (lactam fraction 0.893) and cloxacillin (lactam fraction 0.951) were supplied by Beecham Pharmaceuticals (Batchworth, England). Nafcillin (lactam fraction 1.013) was given by Wyeth International Ltd., (Philadelphia, USA), clavulanic acid was placed at our disposal by Beecham Pharmaceuticals.(Batchworth, England) in the form of a water-free freeze-dried sodium salt. All other reagents were analy tically pure trade products.

\section{Kinetic properties}

The catalytic activity of the $\beta$-lactamase was determined as described by Rossmann et al. (15). The reaction of $p$-chlormercuribenzoate and penicilloic acid obtained from enzymatic hydrolysis of the examined penicillin was monitored spectrophotometrically at $\lambda=250 \mathrm{~nm}$. All measurements were carried out in $0.1 \mathrm{~mol} / 1$ phosphate buffer $\mathrm{pH} 6.8$ at $25^{\circ} \mathrm{C}$. To investigate the enzyme kinetic values $V$ and $K_{\mathrm{m}}$ the substrate concen- trations were varied between $200 \mu \mathrm{mol} / \mathrm{l}$ and $20 \mu \mathrm{mol} / \mathrm{l}$. The limiting factors were the absorption of the substances at the measuring wavelength and a spontaneous reaction which could be observed for some penicillins at higher concentrations only.

The catalytic activity of the enzyme was calculated for each substrate concentration from the change of absorption in the first minute of reaction $(\Delta \mathrm{A} / \mathrm{min})$.

\section{Enzyme inhibition}

In inhibition studies the same amount of inhibitor was added to both the reaction and the comparative mixtures. Again measurements were carried out as described by Rossmann et al. (15).

\section{Absorption coefficients}

Absorption coefficients of the examined penicillins were calculated as described by Rossmann et al. (15). The oorresponding penicilloic acid was obtained by enzymatic hydrolysis. In the case of nafcillin, the method had to be slightly modified. The absorption of the intact naf cillin molecule at $\lambda=250 \mathrm{~nm}$ was so high that the absorption of the mercaptide had to be corrected by the value of the natural absorption of the naphthalene derivative in $0.1 \mathrm{~mol} / 1$ phosphate buffer $\mathrm{pH} 6.8$.

\section{Results}

\section{Absorption coefficients}

Table 1 shows the absorption coefficients $(\lambda=250 \mathrm{~nm})$ of the mercaptides from all examined $\beta$-lactamase susceptible penicillins. Each case showed that LambertBeer's law was valid up to a change of absorption of $\Delta \mathrm{A}=0.5$, i.e. up to a penicilloid concentration of $10 \mu \mathrm{mol} / \mathrm{l}$.

Tab. 1. Validity of Lambert-Beers law and absorption coefficients $(\lambda=250 \mathrm{~nm})$ for $\beta$-lactamase susceptible substrates. The accuracy of the validity ranges is substantiated by correlation coefficients.

\begin{tabular}{lllll}
\hline Substrate & \multicolumn{2}{l}{$\begin{array}{l}\text { Validity range } \\
\Delta \mathrm{A} \Delta \mathrm{c}\end{array}$} & $\begin{array}{l}\text { Correlation } \\
\text { coefficient } \\
\text { up to up to }\end{array}$ & $\begin{array}{l}\text { Ibsorp- } \\
\text { tion } \\
\text { coefficient } \\
\left(\mathrm{cm}^{2} / \mathrm{mol}\right)\end{array}$ \\
\hline Penicillin G-Na & 0.5 & 15 & 0.999 & $8.95 \cdot 10^{6}$ \\
Penicillin V-K & 0.5 & 12 & 0.999 & $9.83 \cdot 10^{6}$ \\
Pheneticillin & 0.5 & 14 & 0.999 & $8.55 \cdot 10^{6}$ \\
Carbenicillin & 0.5 & 12 & 1.000 & $8.57 \cdot 10^{6}$ \\
Ampicillin & 0.6 & 15 & 0.999 & $9.90 \cdot 10^{6}$ \\
Nafcillin & 0.57 & 11 & 0.999 & $9.15 \cdot 10^{6}$ \\
\hline
\end{tabular}

\section{Determination of $K_{\mathrm{m}}$ and $V$}

$K_{\mathrm{m}}$ and $V$ were measured using enzymatically hydrolysable penicillins by varying the substrate concentrations from $20-200 \mu \mathrm{mol} / \mathrm{l}$, i.e. within the range of about 5-95\% substrate saturation of the enzyme. Using ampicillin and propicillin, the determination of the reaction velocities in the substrate range between 20 and $200 \mu \mathrm{mol} / \mathrm{l}$ was not previously possible, due to the spontaneous formation of the mercaptides in the absence of $\beta$-lactamàse. By reducing the substrate concentrations the enzymatic hydrolysis could be registered and $K_{m}$ and $V$ determined without interference by spontaneous hydrolysis. 
In the case of nafcillin the enzyme reaction could be registered only at concentrations of $<20 \mu \mathrm{mol} / \mathrm{l}$. The high absorption rate of the naphthalene ring system interfered with the measurements of the reaction velocities at higher concentrations.

Table 2 shows the results of these studies. The maximum velocity $V(\mathrm{nmol} / \mathrm{min})$ was calculated from $\Delta \mathrm{A} / \mathrm{min}$ by using the equation $\Delta \mathrm{A}=\epsilon_{250} \cdot \mathrm{c} \cdot \mathrm{d}$. For each penicillin the corresponding absorption coefficients (tab. 1) were used.

Tab. 2. Michaelis constants $K_{\mathrm{m}}$ and maximal reaction velocities $V$ for $\beta$-lactamase susceptible penicillins determined graphically by Lineweaver-Burk plots. Listed are the used enzyme dilutions which allowed an objective measurement of the reaction velocities and the correlation coefficients of the Lineweaver-Burk regression curves.

\begin{tabular}{lllll}
\hline Substrate & $\begin{array}{l}\text { Enzyme } \\
\text { dilu- } \\
\text { tion*) }\end{array}$ & $\begin{array}{l}\text { Correla- } \\
\text { tion } \\
\text { coeffi- } \\
\text { cient } \mathrm{r}\end{array}$ & $\begin{array}{l}\boldsymbol{l} \\
(\mathrm{nmol} / \\
\mathrm{min})\end{array}$ & $\begin{array}{l}K_{\mathrm{m}} \\
(\mu \mathrm{mol} / \mathrm{l})\end{array}$ \\
\hline Penicillin G-Na & $1: 200$ & 0.997 & 23.7 & 40.3 \\
Penicillin V-K & $1: 200$ & 0.999 & 10.6 & 41.6 \\
Pheneticillin & $1: 200$ & 0.999 & 7.7 & 143.0 \\
Carbenicillin & $1: 40$ & 9.998 & 16.1 & 88.5 \\
Ampicillin & $1: 20$ & 0.999 & 15.6 & 87.7 \\
Propicillin & $1: 20$ & 0.997 & 18.8 & 41.2 \\
Nafcillin & $1: 3$ & 0.991 & 5.4 & 11.2 \\
\hline
\end{tabular}

*) Lyophilized material was dissolved as specified in the manufacturer's instructions with $2 \mathrm{ml}$ of bidistilled water and diluted to the listed ratio using $0.1 \mathrm{~mol} / \mathrm{l}$ phosphate buffer $\mathrm{pH}$ 6.8.

\section{Enzyme inhibition}

Inhibition studies of the $\beta$-lactamase of Bacillus cereus were carried out using different $\beta$-lactamase stable penicillins and clavulanic acid.

If the substrate concentrations were increased to the necessary range of substrate saturation of the enzyme, the Lineweaver-Burk plot and the $v-\mathrm{p}$ [S] plot (fig. 1) will show a substrate inhibition for some enzymatically hydrolysable penicillins.

Using the $v-\mathrm{p}[\mathrm{S}]$ plot the value of the optimum substrate concentration [S $]_{v_{\text {opt }}}$ and the related optimum reaction velocity $\nu_{\text {opt }}$ can be identified and $V$ and $K_{\mathrm{m}}$ calculated (tab. 3) as described in the discussion.

Standard plots for the enzymatic hydrolysis of $\beta$-lactamase susceptible penicillins in the presence of a $\beta$-lactamase stable penicillin (which acts as an inhibitor of the Bacillus cereus $\beta$ =lactamase) show differing types of inhibition.

The enzymatic hydrolysis of phenethicillin is inhibited competitively in the presence of nafcillin as shown in .the Lineweaver-Burk plot (fig. 2). From the corresponding Dixon plot (18), $K_{i}$ is found to be about $9: 6 \mu \mathrm{mol} / 1$.
In the presence of cloxacillin, with benzylpenicillin as substrate, the Lineweaver-Burk plot shows non-competitive inhibition (fig. 3), and $K_{\mathrm{i}}$ is about $490.3 \mu \mathrm{mol} / \mathrm{l}$ from the Dixon plot (fig. 4).

An uncompetitive type of inhibition was found when carbenicillin was used as substrate and cloxacillin as inhibitor (Fig. 5, 6) $\alpha K_{\mathrm{i}}$ (Model 2) for this type of inhibition is calculated from the Dixon plot to be about $400 \mu \mathrm{mol} / 1$.

Tab. 3. Optimal substrate concentrations for kinetic studies of Bacillus cereus $\beta$-lactamase with various substrates ascertained from $\nu v s \mathrm{p}[\mathrm{S}]$ plots as in fig. 2. $\nu_{\text {opt }}$ and $[\mathrm{S}]_{\nu_{\text {opt }}}$ were calculated from $K_{\mathrm{m}}$ and $V . K_{\mathrm{ESS}}$ was determined graphically.

\begin{tabular}{llllll}
\hline Substrate & $\begin{array}{l}v_{\text {opt }} \\
(\mathrm{nmol} / \\
\mathrm{min})\end{array}$ & $\begin{array}{l}\boldsymbol{V} \\
(\mathrm{nmol} / \mathrm{min})\end{array}$ & $\begin{array}{l}{[\mathrm{S}]_{\nu_{\text {opt }}}} \\
(\mu \mathrm{mol} / \mathrm{l})\end{array}$ & $\begin{array}{l}K_{\mathrm{m}} \\
(\mu \mathrm{mol} / \mathrm{l})\end{array}$ & $\begin{array}{l}K_{\mathrm{ESS}} \\
(\mu \mathrm{mol} / \mathrm{l})\end{array}$ \\
\hline $\begin{array}{l}\text { Peni- } \\
\text { cillin G-Na }\end{array}$ & 3.8 & 4.7 & 371.5 & 48.3 & 2858.6 \\
$\begin{array}{l}\text { Peni- } \\
\text { cillin V-K }\end{array}$ & 7.1 & 11.2 & 190.5 & 54.9 & 661.6 \\
$\begin{array}{l}\text { Pheneti- } \\
\text { cillin }\end{array}$ & 7.0 & 16.7 & 269.1 & 185.0 & 391.6 \\
$\begin{array}{l}\text { Carbeni- } \\
\text { cillin }\end{array}$ & 5.9 & 12.5 & 204.2 & 115.3 & 359.8 \\
\hline
\end{tabular}

Figure 7 shows the influence of clavulanic acid on the enzymatic hydrolysis of benzylpenicillin. The Lineweaver-Burk plot shows a mixed type of inhibition. The Dixon plot (fig. 8) gives a mean $\alpha K_{\mathrm{i}}$ of $37.8 \mu \mathrm{mol} / \mathrm{l}$. The same type of inhibition is found using ampicillin as substrate and clavulanic acid as inhibitor for the Bacillus cereus $\beta$-lactamase (fig. 9). The inhibitor constant $\alpha K_{\mathrm{i}}$ from the Dixon plot has a mean value of $19.1 \mu \mathrm{mol} / \mathrm{l}$.

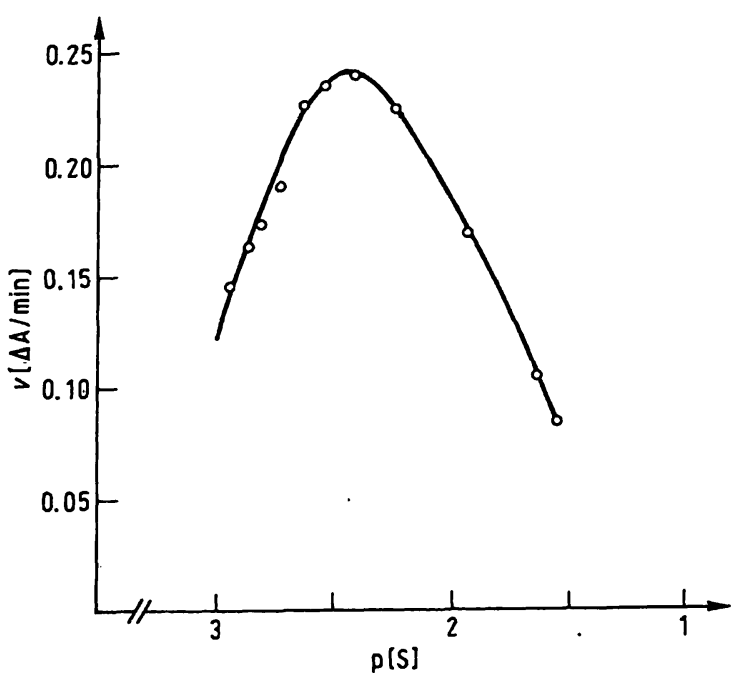

Fig. 1. $v$ vs. p $|S|$ plot of phenethicillin. The top of the curve resembles $\nu_{\text {opt }}$, which is the reaction velocity at the optimal substrate concentration $\left[\left.S\right|_{y_{\text {opt }}}\right.$. 


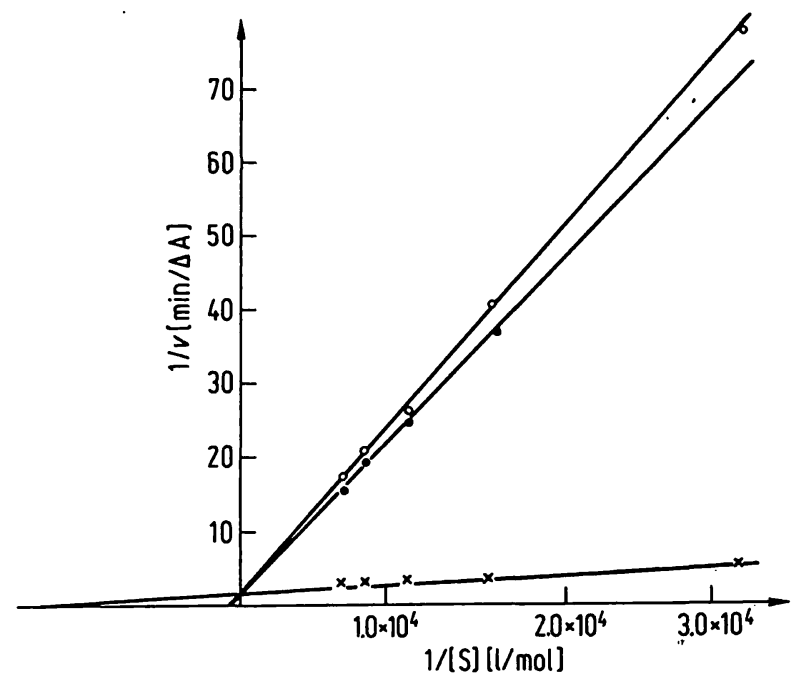

Fig. 2. Competitive inhibition of phenethicillin (S) by nafcillin (I).

$x-x$ uninhibited reaction, $[\mathrm{I}]=0.0 \mu \mathrm{mol} / 1$

$\bullet[\mathrm{I}]=52.5 \mu \mathrm{mol} / 1$

$\circ \multimap \circ[\mathrm{I}]=65.7 \mu \mathrm{mol} / \mathrm{l}$

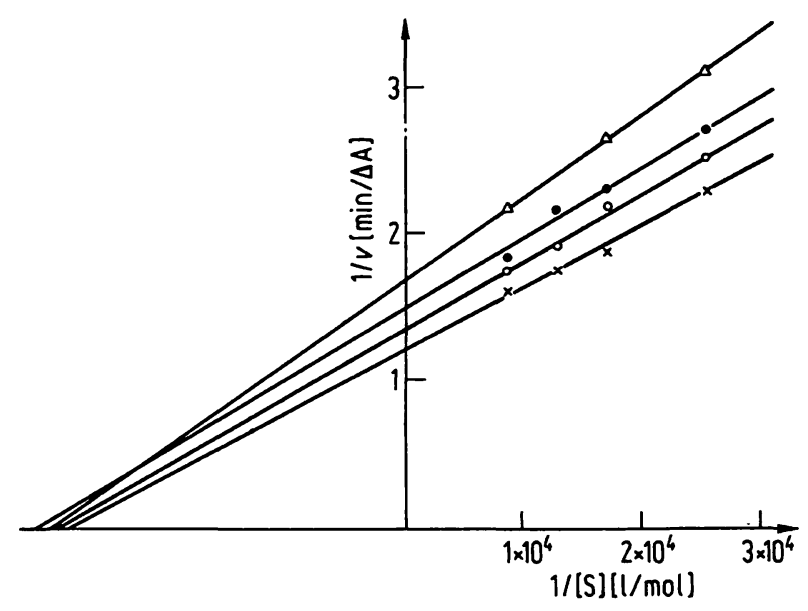

Fig. 3. Lineweaver-Burk-plot of benzylpenicillin (S) alone and in the presence of cloxacillin (I) as inhibitor

$x-x$ uninhibited reaction, $[\mathrm{I}]=0.0 \mu \mathrm{mol} / \mathrm{l}$

$\circ \longrightarrow$ [I] $=97.9 \mu \mathrm{mol} / 1$

$\bullet \longrightarrow[\mathrm{I}]=122.3 \mu \mathrm{mol} / \mathrm{l}$

$\Delta-\Delta[\mathrm{I}]=195.7 \mu \mathrm{mol} / \mathrm{l}$

\section{Discussion}

\section{Absorption coefficients}

Rossmann et al. (15) first described a spectrophotometric method for penicillin and penicillinase determinations. The chemical reactions are shown in figure 10.

The penicillamine-mercuribenzoate is determined for each case. The almost correspondent values of the molar absorption coefficients of the examined penicillins (tab. 1) indicate that the reaction via the penamaldate upon the penicillamine-mercuribenzoate is complete. The mercaptide of the formed penicillamine is measured under the chosen experimental conditions for all studied substrates.

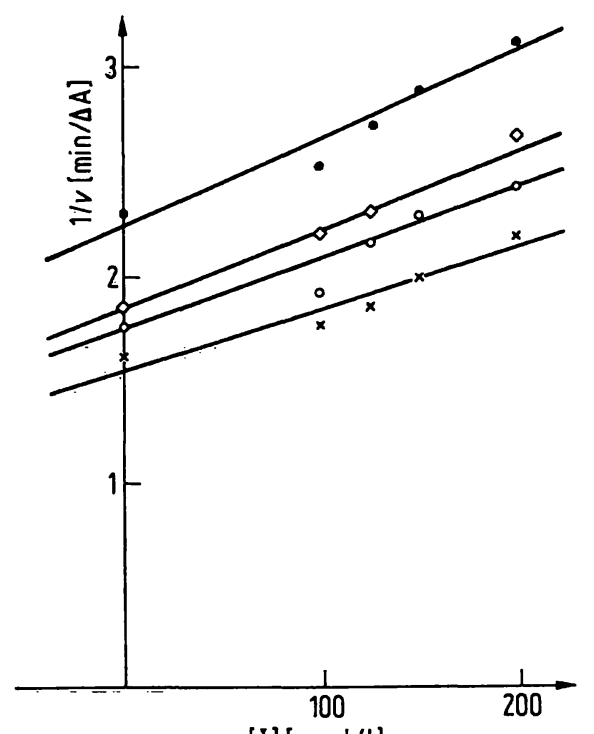

[I] [umol/l]

Fig. 4. 1/v vs. [I] plot for cloxacillin (I) as inhibitor and benzylpenicillin as substrate. $x-x[S]=177.3 \mu \mathrm{mol} / 1$ $0-0[\mathrm{~S}]=78.2 \mu \mathrm{mol} / \mathrm{l}$ $\diamond-\diamond[S]=58.7 \mu \mathrm{mol} / 1$ $\bullet[\mathrm{S}]=39.1 \mu \mathrm{mol} / 1$

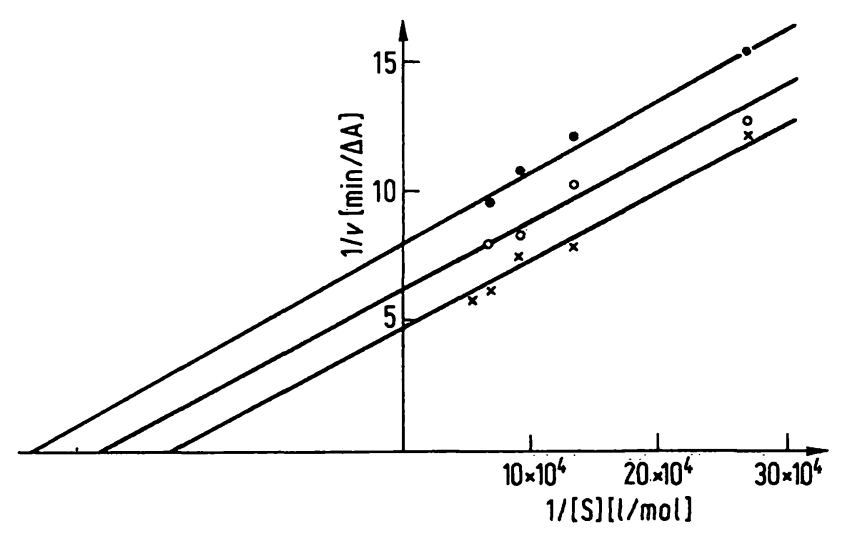

Fig. 5. "Uncompetitive" pattern of inhibition of carbenicillin (S) hydrolysis by cloxacillin.

$x-x$ uninhibited reaction, $[\mathrm{I}]=0.0 \mu \mathrm{mol} / \mathrm{l}$

$\circ-0[\mathrm{I}]=122.3 \mu \mathrm{mol} / \mathrm{l}$

$\bullet-[\mathrm{I}]=195.7 \mu \mathrm{mol} / \mathrm{l}$

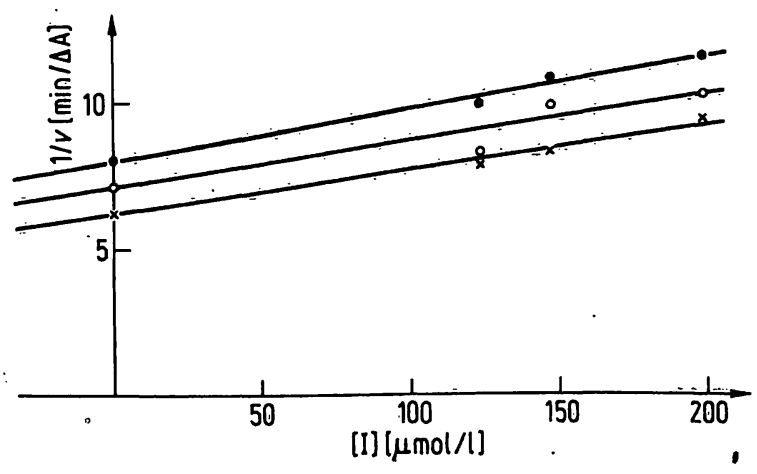

Fig. 6. $1 / v$ vs. [I] plot for cloxacillin (I) as inhibitor and carbenicillin (S) as substrate.

$x-x \quad[S]=177.3 \mu \mathrm{mol} / 1$

$\circ-0[S]=78.2 \mu \mathrm{mol} / \mathrm{l}$

$\bullet[\mathrm{S}]=58.7 \mu \mathrm{mol} / \mathrm{l}$ 


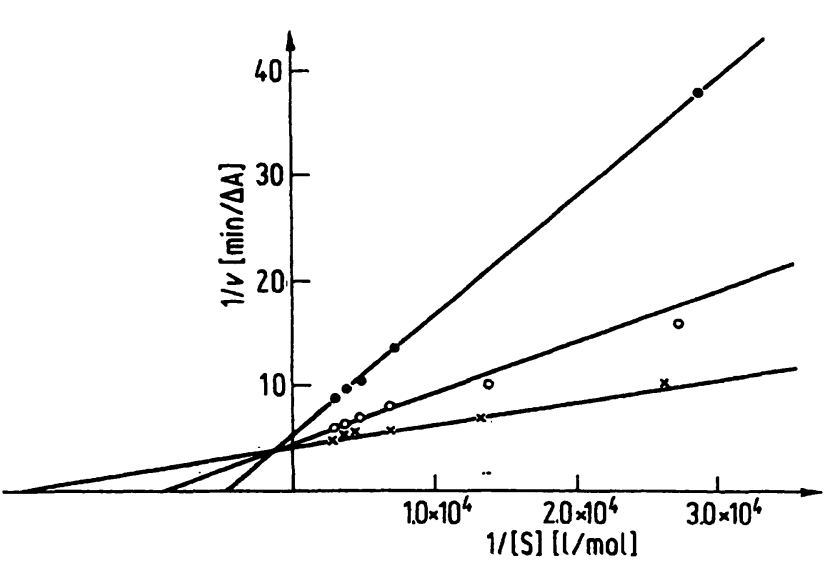

Fig. 7. Lineweaver-Burk plot for benzylpenicillin (S) alone and in the presence of clavulanic acid (I) as inhibitor. $x-x$ uninhibited reaction, $[\mathrm{I}]=0.0 \mu \mathrm{mol} / \mathrm{l}$ 0 - $[\mathrm{I}]=37.7 \mu \mathrm{mol} / 1$ $\bullet-[\mathrm{I}]=89.2 \mu \mathrm{mol} / \mathrm{l}$

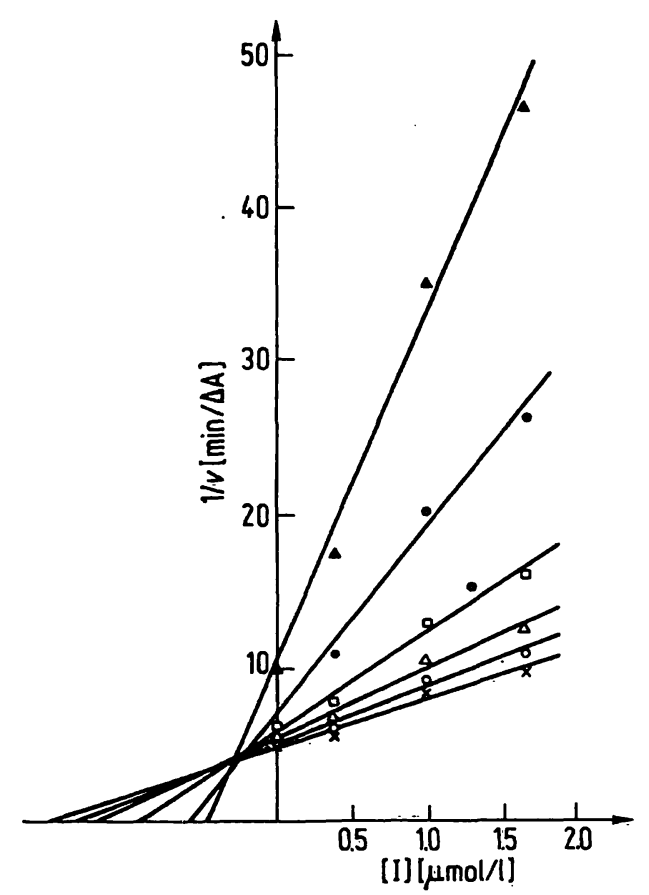

Fig. 8. 1/v vs. [I] plot for clavulanic acid (I) as inhibitor and benżylpenicillin (S) as substrate

$x \rightarrow x[S]=10.0 \cdot 10^{3} \mu \mathrm{mol} / 1$

$\circ$ ○ $[S]=8.0 \cdot 10^{3} \mu \mathrm{mol} / 1$

$\Delta \longrightarrow \Delta[\mathrm{S}]=6.0 \cdot 10^{3} \mu \mathrm{mol} / 1$

$0=0[S]=4.0 \cdot 10^{3} \mu \mathrm{mol} / \mathrm{l}$

$\bullet[S]=2.0 \cdot 10^{3} \mu \mathrm{mol} / 1$

$\triangle[\mathrm{S}]=1.0 \cdot 10^{3} \mu \mathrm{mol} / 1$

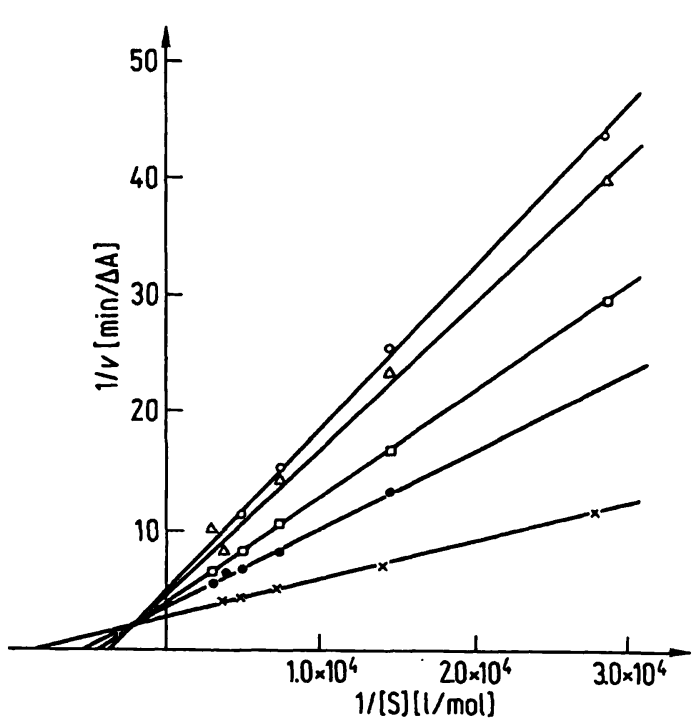

Fig. 9. Lineweaver-Burk plot for ampicillin (S) alone and in the presence of clavulanic acid (I) as inhibitor $x \longrightarrow x$ uninhibited reaction, $[\mathrm{I}]=0.0 \mu \mathrm{mol} / 1$

$\bullet[\mathrm{I}]=19.0 \mu \mathrm{mol} / \mathrm{l}$

口- [I] $=37.0 \mu \mathrm{mol} / 1$

$\Delta-\Delta[\mathrm{I}]=56.0 \mu \mathrm{mol} / \mathrm{l}$

$\circ \longrightarrow[I]=74.0 \mu \mathrm{mol} / 1$

\section{Kinetic constants}

The hydrolysis of benzylpenicillin by $\beta$-lactamase is described by Michaelis-Menten kinetics (19). For this reason we determined $V$ and $K_{\mathrm{m}}$ for some enzymatically hydrolysable penicillins (tab. 2), in order to characterize a Bacillus cereus $\beta$-lactamase. An interesting finding was that nafcillin, which is thought to be $\beta$-lactamase stable, was hydrolysed by the investigated $\beta$-lactamase. The affinity to the catalytic site of the enzyme expressed by $K_{\mathrm{m}}$ (tab. 2) was the highest of all examined $\beta$-lactamase susceptible penicillins, whereas, as expected, the maximum velocity $(V)$ was the lowest. From these data competitive inhibition was anticipated when nafcillin was used as inhibitor (fig. 2).

\section{Substrate inhibition}

Increasing the substrate concentration up to saturation of the enzyme, results in a progressive inhibition of the $\beta$-lactamase. For the lower substrate concentrations, Michaelis-Menten kinetics are also valid (uninhibited reaction). $V$ and $K_{\mathrm{m}}$ can be ascertained graphically from the

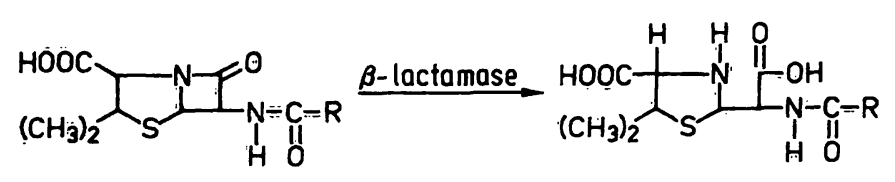

Penicillin

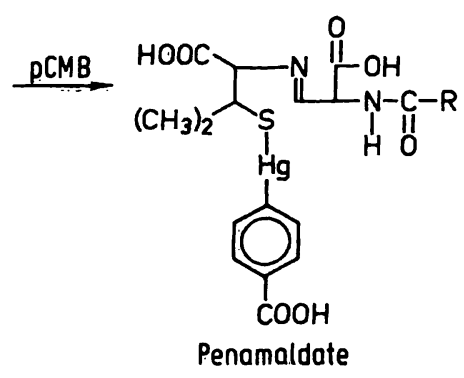

Fig. 10. Pathway for the determination of $\beta$-lactamase by the use of $p$-chloromercuribenzoate ( $p C M B)$. 
values in the lower concentration range (uninhibited reaction) plotted as $1 / v$ vs. $1 /[\mathrm{S}]$. The observed phenomenon of substrate inhibition can be described by an extended Michaelis-Menten pattern (Model 1). The enzyme substrate complex is able to bind another substrate molecule reversibly at a catalytically ineffective second binding site.

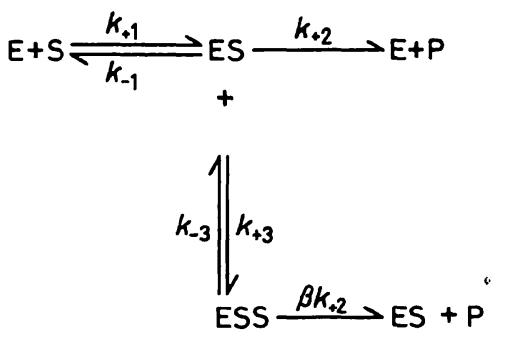

Model 1

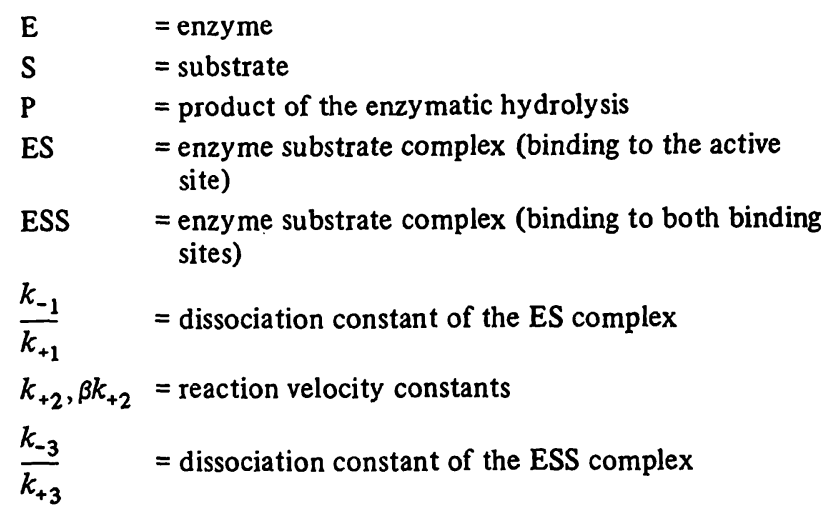

In the most simple case the ESS complex shows no catalytic activity, i.e. $\beta=0$. For substrates showing a substrate inhibition this assumption is valid if, in the $v-\mathrm{p}[\mathrm{S}]$ plot, the curve is symmetrical. The rate equation for this reaction is

$$
v=\frac{V \cdot[\mathrm{S}]}{K_{\mathrm{m}}+[\mathrm{S}]+\frac{[\mathrm{S}]^{2}}{K_{\mathrm{ESS}}}}
$$

For equation 1:

$$
K_{\mathrm{ESS}}=\frac{k_{-3}}{k_{+3}}
$$

$K_{\text {ESS }}$ is the dissociation constant of the ESS-complex. From the $v-\mathrm{p}[\mathrm{S}]$ plot the value of the optimal substrate concentration $[S]_{v_{o p t}}$, i.e. the concentration of substrate at which the enzyme possesses an optimum catalytic activity $v_{\text {opt }}$, can be identified directly.

From equation 1 the following connection is valid, if

$$
\begin{aligned}
& \frac{\mathrm{d}(1 / v)}{\mathrm{d} 1 /[\mathrm{S}]}=0 \\
& \frac{[\mathrm{S}]_{v_{\text {opt }}}}{K_{\mathrm{ESS}}}=\frac{K_{\mathrm{m}}}{[\mathrm{S}]_{v_{\text {opt }}}}
\end{aligned}
$$

or transformed

$$
[S]_{v_{\text {opt }}}=\sqrt{K_{\mathrm{m}} \cdot K_{\mathrm{ESS}}}
$$

With the graphically determined values for $[S]_{v_{o p t}}$ and $\nu_{\text {opt }}, K_{\mathrm{m}}$ and $V$ can be calculated as follows. The optimum velocity $\nu_{\text {opt }}$ can be attained by placing $[S]_{\nu_{\text {opt }}}$ into the common rate equation (eq 1).

$$
v_{\mathrm{opt}}=V \cdot \frac{1}{\frac{K_{\mathrm{m}}}{[\mathrm{S}]_{v_{\mathrm{opt}}}}+1+\frac{[\mathrm{S}]_{v_{\mathrm{opt}}}}{K_{\mathrm{ESS}}}}
$$

Substituting equation $2 \mathrm{a}$ for equation 3 we get

$$
V=v_{\text {opt }}\left(1+2 \frac{K_{\mathrm{m}}}{[\mathrm{S}]_{v_{\mathrm{opt}}}}\right)
$$

Furthermore

$$
\frac{v_{\mathrm{opt}}}{2}=V \cdot \frac{1}{\frac{K_{\mathrm{m}}}{[\mathrm{S}]_{v_{\mathrm{opt} / 2}}}+1+\frac{[\mathrm{S}]_{v_{\mathrm{opt} / 2}}}{K_{\mathrm{ESS}}}}
$$

Division of equation 3 by equation 5 , transformation and inclusion into equation $2 a$ will result in

$$
\frac{K_{\mathrm{m}}}{[\mathrm{S}]_{v_{\text {opt }}}}=\frac{1}{\frac{[\mathrm{S}]_{v_{\text {opt }}}}{[\mathrm{S}]_{v_{\text {opt } / 2}}}+\frac{[\mathrm{S}]_{v_{\text {opt } / 2}}}{[\mathrm{~S}]_{v_{\text {opt }}}}-4}
$$

Inclusion of equation 6 in equation 4 will result in the required relation (eq 7), of $V$ to the experimentally determined values of $v_{\mathrm{opt}}$ and $[S]_{v_{\mathrm{opt}}}$.

$$
V=v_{\text {opt }}\left(1+\frac{2}{\frac{[\mathrm{S}]_{v_{\text {opt }}}}{[\overline{\mathrm{S}}]_{v_{\mathrm{opt} / 2}}}+\frac{[\mathrm{S}]_{v_{\mathrm{opt} / 2}}}{[\mathrm{~S}]_{v_{\mathrm{opt}}}}-4}\right)
$$

After calculating $V$ by using equation $7, K_{\mathrm{m}}$ can be calculated from equation 4: $K_{\mathrm{m}}$-values calculated in this way and listed in tables 2 and 3 are therefore not equal. This is because all measured values, including those of the substrate inhibition, were used for the calculation of the values for table 3 , whereas for the calculation of the values of table 2 only the measured values of the uninhibited reaction were used.

All the listed $K_{\mathrm{m}}$-values in table 3 are higher than the $K_{\mathrm{m}}$-values determined by the Lineweaver-Burk plot.

\section{Second substrate binding site}

Corresponding to Model 2 the substrate inhibition can be defined as an uncompetitive type of inhibition. In this case the substrate, acting as inhibitor, reacts with the ES complex by creating a "ternary" ESS complex without disintegration into a product, i.e. $\beta=0$. As result of our experimentally determined substrate inhibition, which is clearly described by the model of an un- 


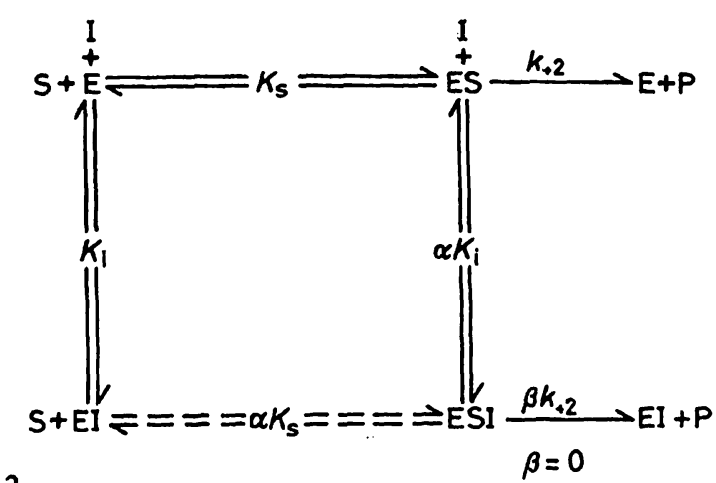

Model 2 $\beta=0$

$\mathrm{E} \quad=$ enzyme

$\mathrm{S} \quad=$ substratc

$\mathrm{P} \quad$ = product of the enzymatic hydrolysis

I $\quad=$ inhibitor

$K_{\mathrm{S}}, \alpha K_{\mathrm{S}}$, = dissociation constants

$K_{\mathbf{i}}, \alpha K_{\mathbf{i}}$

ES = enzyme substrate complex

EI = enzyme inhibitor complex

ESI = enzyme-substrate-inhibitor complex (binding of the substrate to the active site)

$k_{+2}, \beta k_{+2}=$ reaction velocity constants

competitive type of inhibition, it can be deduced that the examined $\beta$-lactamase possesses a further substrate binding site separate from the catalytical active binding site. The dissociation constant $K_{\text {ESS }}$, which characterizes the second substrate binding site on the enzyme, is $50 \times$ and $12 \times$ higher than $K_{\mathrm{m}}$ for benzylpenicillin and phenoxymethylpenicillin, respectively. In case of phenoxyethylpenicillin and carbenicillin this constant is about twice as high as $K_{\mathrm{m}}$ (tab. 3). For these penicillins there seems to be a relatively high affinity to the second catalytically inactive binding site. With regard to the postulated uncompetitive mechanism, which describes the substrate inhibition, the formation of the ESS complex is a prerequisite for this high affinity of the second substrate molecule.

Our theory of multiple binding sites on the studied $\beta$-lactamase is in agreement with observations by other authors $(8,20)$. Further support for the acceptance of a second substrate binding site on the $\beta$-lactamase could be deduced from inhibition studies with $\beta$-lactamase stable penicillins. To describe this reaction, model 1 , which was has already been used to describe an uncompetitive type of inhibition, has been extended (model 2, compare 1.c. (21)). The substrate can be considered to act as a substrate (S) and as an inhibitor (I), which binds reversibly both to the native enzyme (to form EI) and to the enzyme substrate complex (to form ESI).

The enzymatic hydrolysis of pheneticillin is inhibited competitively in the presence of nafcillin, as shown by the Lineweaver-Burk plot (fig. 2). This type of inhibition was also found by other authors $(6,7,22)$, partly by using other substrates. Due to the fact that these studies were carried out with phenoxyethylpenicillin concentrations for which no substrate inhibition could be established, the substantially absent effect of the second catalytically inactive site upon the catalytically active site may be disregarded. In this experimental design the non-catalytic binding site has no detectable influence on inhibition of the enzyme.

As presumed by the relatively high affinity for the inhibitor for the active site of the enzyme (tab. 2), nafcillin was a potent competitive inhibitor in our experiments. A similar observation was made in a different connection by other authors (23).

The influence of cloxacillin on the enzymatic hydrolysis of benzylpenicillin differs from the described type of inhibition. The Lineweaver-Burk plot does not show a pure type of inhibition but a change from a non-competitive type to an uncompetitive type. In the case of cloxacillin the binding tendency of the inhibitor with the enzyme substrate complex ES is higher than with the native enzyme $E$, so that $\alpha \leqslant 1$ (model 2).

If carbenicillin, a substrate with a remarkably increased tendency to bind to the second non catalytically active binding site, is used in inhibition studies with cloxacillin the Lineweaver-Burk plot shows an uncompetitive type of inhibition. As in the case of substrate inhibition, the inhibitor reacts almost solely with the enzyme substrate complex. ES. From both studies using cloxacillin as inhibitor it may be concluded that no noticeable binding of cloxacillin to the second substrate binding site of the $\beta$-lactamase is found under the described examination conditions (fig. 5, 6). This conclusion is supported by the appearance of a mixed type of inhibition with a noncompetitive part for cloxacillin when benzylpenicillin is used as substrate (fig. 4). Strom et al. $(10,24)$ found a competitive type of inhibition for a $\beta$-lactamase of Bacillus cereus when isoxazolylpenicillin was incubated together with a $\beta$-lactamase-susceptible substrate. Preincubation of inhibitor and enzyme results in an uncompetitive type of inhibition. In addition, the temperature of the incubation plays a decisive role in the resulting inhibition type. They too postulated a binding site not involved in the mechanism of hydrolysis. Samuni \& Citri (25) interpreted the observed decrease of catalytical activity after incubation with cloxacillin at $37^{\circ} \mathrm{C}$ as a conformational change of the enzyme. This conformational change results in a destabilisation of the enzyme induced by the substrate, resulting in an increasing inactivation. We believe that the mechanism of cloxacillin inhibition involves binding of the inhibitor to the non-catalytic active binding site. This binding results in a molecular modification of the enzyme, which is best described by the term "conformational change" (26). Thus the activity of the enzyme is decreased; the substrate, on the other hand, affects the affinity of the inhibitor for the non-cataly tic active site. 
Clavulanic acid (fig. 11) acts as an inhibitor for several $\beta$-lactamases from Gram negative bacteria, including Richmond type III $E$. coli $\beta$-lactamases $(14,27)$. Investigations with a $\beta$-lactamase from Staphylococci showed that the observed inhibition of the enzyme is fully reversible (28).<smiles>O=C(O)/C=C1/OC2CC(=O)N2C1C(=O)O</smiles>

Fig. 11. Structure of clavulanic acid, Z-(2R, 5R)-3-( $\beta$-hydroxyethylidene)-7-oxo-4-oxa-1-azabicyclo-[3.2.0] heptane-2carboxylic acid.

It was therefore interesting to investigate whether the structural variations of clavulanic acid compared with those of penicillin result in differences in affinity to the two postulated binding sites. Inhibition studies with benzylpenicillin and ampicillin as substrates resulted in a mixed type of inhibition (fig. 7, 8,9). Using model 2 the observed type of inhibition may be interpreted as partial competitive - noncompetitive i.e. $\infty>\alpha>1$ and $\beta=0$. The similarities in the molecular structure of clavulanic acid and the penicilloic acid portion of the penicillins are sufficient to effect an annexion to the active center of the enzyme.

This finding of a mixed type of inhibition for clavulanic acid is made on the assumption that the reaction is fully reversible. It was recently shown that a $\beta$-lactamase from E. coli (Richmond type III) reacts irreversibly with clavulanic acid $(14,27)$. If, contrary to our assumption of full reversibility, the reaction of the Bacillus cereus $\beta$-lactamase were also irreversible, the observed mixed type of inhibition could be misleading, and our conclusions would be unjustified.

On the other hand, Reading et al. (28) found that although clavulanic acid reacts with an enzyme preparation of Staphylococcus aureus by forming a relatively stable intermediate product with covalent binding, the reaction can be shown to be fully reversible. If the possibility of a relatively stable intermediate is taken into account, a slowly decaying acetylated intermediate must be included in the reaction model. The experimental elucidation will require time course studies and dialysis experiments.

\section{Conclusion}

From the results of our experiments it may be concluded that the examined $\beta$-lactamase from Bacillus cereus possesses, separate from the active site, a second substrate binding site without catalytic activity. Binding of molecules with $\beta$-lactam structure to this site causes changes in the enzyme kinetic parameters, $K_{\mathrm{m}}$ and $V$.

\section{Acknowledgements}

We gratefully acknowledge the supply of the penicillins and clavulanic acid by the manufacturers Bayer, Beecham, Hoechst and Wyeth and of the penicillinase (Neutrapen ${ }^{\circledR}$ ) by Kettelhack Riker Pharma GmbH, D-4280 Borken.

We wish to thank Corinne Sidler and Gudrun Welge for their excellent technical assistance and Leila Braun for her careful secretarial assistance.

\section{References}

1. Abraham, E. P. \& Chain, E. (1941) Nature (London) 146 , 827.

2. Barber, M. (1947) J. Pathol. Bacteriol. 59, 373-384.

3. Spink, W. W. \& Ferris, V. (1947) J. Clin. Invest. 26, 376393.

4. Hamilton-Miller, I. M. T., Smith, J. T. \& Knox, R. (1964) Nature (London) 201, 867-868.

5. Sutherland, R. \& Batchelor, F. R. (1964) Nature (London) 201, 868-869.

6. Selzer, G. B. \& Wright, W. W. (1964) Antimicrob. Ag. Chemother. 311-314.

7. Citri, N. \& Pollock, R. (1966) Adv. Enzymol. 28, 237-323.

8. Csanyi, V., Mill, I., Koczka, I., Badar, E. \& Horvath, I. (1970) Biochim. Biophys. Acta 220, 317-325.

9. O'Callaghan, C. H. \& Morris, A. (1972) Antimicrob. Ag. Chemother. 2, 442-448.

10. Strom, R., Renzini, G., Ravagnan, G. \& Rossi Fanelli, F. (1974) FEBS Lett. 43, 49-52.

11. Hata, T., Omura, S., Iwai, Y., Okuo, H., Takeskima, H. \& Yamaguchi, N. (1972) J. Antibiotics 25, 473-474.

12. Brown, A. G., Butterworth, D., Cole, M., Hanscomb, G., Hood, J. D. \& Reading, C. (1976) 668-669.

13. Reading, C. \& Cole, M. (1977) Antimicrob. Ag. Chemother. $11,852-857$

14. Neu, H. C. \& Fu, K. P. (1978) Antimicrob. Ag. Chemother. $14,650-655$.

15. Rossmann, I., Siegmund, P. \& Körber, F. (1970) Z. Anal. Chem. 252, 199-203.

16a. Levy, G. B. (1958) Nature (London) $166,740-741$.

16b. Kuwabara, S. (1970) Biochem. J. 118, 457-465.

16c. Sabath, L. D. \& Abraham, E. P. (1965) Antimicrob. Ag Chemother. 5, 392-397.

17. Körber, F., Moderson, D. \& Siegmund, P. (1968) Z. Klin. Chem. Klin. Biochem. 6, 289-293.

18. Dixon, M. (1953) Biochem. J. 55, 170-171.

19. Banfield, J. E. (1957) Experientia 13, 403-404.

20. Virden, R., Bristow, A. F. \& Pain, M. (1978) Biochem. Biophys. Res. Commun. $82,951-956$.

21. Webb, J. L. (1963) Enzyme and Metabolic Inhibitors, Vol. 1, General Principles of Inhibition, Academic Press, New York, London.

22. Cole, M., Elson, S. \& Fullbroof, P. D. (1972) Biochem. J. 127, 295-308.

23. Greenwood, D. \& O'Grady, F. (1975) Chemother. 21, 330341.

24. Strom, R., Ravagnan, G. \& Salfi, V. (1976) Eur. J. Biochem. 62, 95-101.

25. Samuni, A. \& Citri, N. (1975) Biochem. Biophys. Res. Commun. 62, 7-11.

26. Citri, N. \& Zyk, N. (1967) Biochem. Biophys. Res. Commun. $26,216-220$.

27. Fisher, J., Charnas, R. L. \& Knowles, J. R. (1978) Biochemistry 17, 2180-2184.

28. Reâding, C. \& Hepburn, P. (1979) Biochem. J. 179, 67-76.

Dr. R. Müneh

Universitätsspital Zürich

Department für Innere Medizin

Medizinische Poliklinik

CH-8091 Zürich 